\title{
Atmospheric deposition of polychlorinated dibenzo-dioxins/furans (PCDD/ Fs), polychlorinated biphenyls (PCBs) and polybrominated diphenyl ethers (PBDEs) in the vicinity of shredding facilities in Wallonia (Belgium)
}

\author{
Patrice Dufour $^{\mathrm{a},{ }^{*}, \text { Catherine Pirard }}{ }^{\mathrm{a}}$, Geoffrey Ortegat ${ }^{\mathrm{b}}$, Jean-Marc Brouhon ${ }^{\mathrm{c}}$, \\ Corinne Charlier ${ }^{\text {a }}$ \\ ${ }^{a}$ Laboratory of Clinical, Forensic and Environmental Toxicology, University of Liege (ULiege), CHU (B35), 4000, Liege, Belgium \\ ${ }^{\mathrm{b}}$ Analyses Unit, Institut Scientifique de Service Public (ISSeP), 7340, Colfontaine, Belgium \\ ${ }^{\mathrm{c}}$ Walloon Agency for Air and Climate, Public Service of Wallonia, Jambes, Belgium
}

\section{A R T I C L E I N F O}

\section{Keywords:}

Shredding facilities

Dry deposition flux

Polychlorinated dibenzo-dioxins/furans

Polychlorinated biphenyls

Polybrominated diphenyl ethers

\begin{abstract}
A B S T R A C T
In Belgium, 16 shredding facilities manage annually tens of thousands tons of wastes from different origins (endof-life vehicles, electronic waste, electrical transformers, ...). These materials contain hazardous persistent organic pollutants such as polychlorinated dibenzo-dioxins/furans (PCDD/Fs), polychlorinated biphenyls (PCBs) and polybrominated diphenyl ethers (PBDEs). The shredding process promotes the production and the emission of dust contaminated by these compounds. The objective of this study is to measure the concentrations of PCDD/ Fs, PCBs and PBDEs in fallout dust collected in the vicinity of 3 shredding plants located in Wallonia (French speaking part of Belgium). Samples were collected by using Owen gauges and pollutant levels were measured by GC-MS. The median deposition levels measured for $\sum$ PCDD/Fs, $\sum$ dioxin-like PCBs, $5 \times \sum 6$ DIN PCBs and PBDE 209 were $1.9 \mathrm{pg}$ TEQ $/ \mathrm{m}^{2}$.day, $4.4 \mathrm{pg} \mathrm{TEQ} / \mathrm{m}^{2}$.day, $246.5 \mathrm{ng} / \mathrm{m}^{2}$.day and $253.8 \mathrm{ng} / \mathrm{m}^{2}$.day, respectively. These levels represent high concentrations compared to those observed in most of the remote, rural and urban areas studied around the world and were similar to those measured in other heavily industrialized districts. Consequently, the health effects of this high exposure to pollutants among workers and residents in the vicinity of these shredding facilities are of concern.
\end{abstract}

\section{Introduction}

Every year, in Europe, more than 6 million metric tons of wastes are generated from the end-of-life vehicles (ELVs). Among them, about 65,000 metric tons are managed in 16 shredding facilities located in Belgium (Reporting, 2019; ECJ European Court of Justice, 2008). Besides ELVs, shredding plants also treat other end-of-life metal goods such as electrical transformers and capacitors, electronic waste (e-waste), metal furniture, etc. In shredders, metal wastes are fragmented into smaller pieces. This process releases heat through the conversion by friction of the electrical power of huge motors (first and second law of thermodynamics; temperature in shredding chamber may reach $70{ }^{\circ} \mathrm{C}$ ) and generates some particles with higher surface/volume ratio. These conditions are favorable to the emission of semivolatile chemicals such as polychlorinated dibenzo-dioxins/furans (PCDD/Fs), polychlorinated biphenyls (PCBs) and polybrominated diphenyl ethers (PBDEs) recognized by the Stockholm Convention as persistent organic pollutants (POPs). According to the Stockholm Convention, one of the main characteristics of the POPs is to be toxic to humans and the environment.

$\mathrm{PCDD} / \mathrm{Fs}$ are chemicals unintentionally produced during incomplete combustion. These compounds present a large panel of toxicological effects mediated through their affinity to the aryl hydrocarbon receptor (AhR) (Van den Berg et al., 2006). Some PCDD/Fs are classified as carcinogenic to human (Group 1) by the International Agency for Research on Cancer (IARC) (Baan et al., 2009). PCBs were produced as technical mixtures and used for a wide range of applications: dielectric fluids for capacitors and transformers, plasticizers in paints, flame retardants, diluents for pesticides, etc. (Reddy et al., 2019). Health issues associated with these compounds are numerous, in particular, effects on the reproductive or the thyroid system are well documented (Bergman

\footnotetext{
Peer review under responsibility of Turkish National Committee for Air Pollution Research and Control.

* Corresponding author.

E-mail address: pdufour@chuliege.be (P. Dufour).
} 
et al., 2013; Boas et al., 2012). Moreover, PCBs are classified as carcinogenic by the IARC (Lauby-Secretan et al., 2013) and some congeners, called dioxin-like PCBs (dl-PCBs), also present affinity for AhR (Van den Berg et al., 2006). PBDEs belong to the family of the brominated flame retardants, these chemicals were incorporated in many consumer products (vehicles, electronic products, clothes, etc.) in order to reduce their inflammability. PBDEs are suspected to be thyroid disruptors (Boas et al., 2012), neurotoxic (Dingemans et al., 2011) or to reduce women's fertility (Harley et al., 2010). Moreover, Montalbano et al. (2020) demonstrated in vitro the cytotoxic and genotoxic effects of PBDEs in human bronchial epithelial cells. Consequently, the health concern associated with the potential emission of these compounds by shredding facilities is far from being negligible.

However, few studies assessed the contamination by these pollutants in the vicinity of shredding plants. Hearn et al. (2012) determined the concentrations of PBDEs in air samples collected in the neighborhood of an automobile shredding facility in Brisbane (Australia). PBDEs levels were also measured by Cahill et al. (2007) in air samples collected near a metal recycling plant based in California (USA). François et al. (2004) assessed the deposition of PCDD/Fs and dl-PCBs near 4 Flemish (Dutch speaking part of Belgium) metal shredding facilities. To the best of our knowledge, no other investigation assessed the atmospheric emissions of POPs by shredding plants and, in particular, no data are available for non-dioxin-like PCBs.

The aim of this study is to measure the concentrations of 17 PCDD/ Fs, 18 PCBs (among which 12 dl-PCBs) and 24 PBDEs in fallout dust collected in the vicinity of 3 shredding plants located in Wallonia (French speaking part of Belgium).

\section{Material and methods}

\subsection{Sampling}

The "Poussière sédimentable" (Fallout Dust) network is one of the air quality monitoring networks in Wallonia. Actually, 147 sampling spots are spread over the territory of Wallonia mainly around the Sambre and Meuse Line (one of the main industrial region in Belgium). The objective of this network is to assess the deposition of toxic elements (mainly metal elements) around heavy industry facilities. The present study involved 13 sampling spots located around 3 shredding facilities. The study was originally designed to assess the deposition of PCBs and PBDEs in the vicinity of the site 1 . Given the important contamination highlighted during the first campaign of collection, the analyses were extended to PCDD/Fs in the following collection campaigns and new samplers have been installed in the surrounding area of two other shredding plants (site 2 and 3). The locations of the sampling spots relative to stack of shredders (direction and distance) were reported in Table 1. In Wallonia, the prevailing winds blow from south-west. Sampling of fallout dust was performed using plastic Owen gauges. These gauges' volume was $10 \mathrm{~L}$ and the diameter of the collecting funnels was

Table 1

Position of the samplers relative to shredders.

\begin{tabular}{llll}
\hline Site & Sampler & Direction & Distance (m) \\
\hline Site 1 & Sampler 1 & WNW & 192 \\
& Sampler 2 & WSW & 165 \\
& Sampler 3 & NNE & 263 \\
& Sampler 4 & E & 178 \\
Site 2 & Sampler 5 & N & 703 \\
& Sampler 1 & ENE & 245 \\
& Sampler 2 & S & 217 \\
& Sampler 3 & NE & 300 \\
Site 3 & Sampler 4 & NW & 463 \\
& Sampler 1 & WSW & 642 \\
& Sampler 2 & NNW & 271 \\
& Sampler 3 & NE & 438 \\
& Sampler 4 & E & 895 \\
\hline
\end{tabular}

$0.3 \mathrm{~m}$. Sampling period durations were reported in Table 2. Four sampling campaigns were performed in site 1 and a single was carried out in each site 2 and 3 . Prior to extraction, dust were dried at $40^{\circ} \mathrm{C}$.

\subsection{Extraction and analyses}

Pre-dried dust samples were analyzed for PCDDs, PCDFs, PCBs and PBDEs by Eurofins GfA Lab Service (Hamburg, Germany). The analytical methods used were DIN EN ISO/IEC 17025:2005 accredited. Dried dust samples were weighted and the deposition fluxes were calculated as follows:

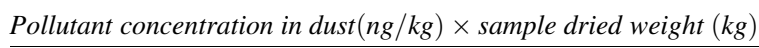
$0.07069 m^{2} \times$ sampling duration (days)

\subsection{1. $P C D D s / P C D F s$ and $P C B s$}

Dust samples were analyzed for 17 PCDDs/PCDFs $(2,3,7,8$ substituted congeners), 12 dioxin-like PCBs (dl-PCBs) (namely PCBs $-77,-81,-105,-114,-118,-123,-126,-156,-157,-167,-169$, -189 ) and non-dl-PCBs (namely PCBs $-28,-52,-101,-138,-153$, -180 ) analogously to DIN-UDI 3499 . Briefly, dried samples were spiked with a mixture of ${ }^{13} \mathrm{C}_{12}$-labeled internal standards (for each native congener, the corresponding ${ }^{13} \mathrm{C}_{12}$-labeled standard was added) and extracted in a Soxhlet apparatus (solvents were ultratrace-analyzes quality). Extracts were cleaned up using a multi-column chromatography system (involving silica gel acidified with sulfuric acid and alumina oxide). Recovery yields were determined by the addition of a ${ }^{13} \mathrm{C}_{12}$ labeled recovery standard. Compounds were analyzed by using a high resolution gas chromatography coupled to a high resolution mass spectrometer (HRGC/HRMS, Waters Autospec, Eschborn, Germany, or DFS mass spectrometers, Thermo Fisher Scientific, Bremen, Germany). Two isotope masses were measured for each compounds. The quantification was performed using the isotope dilution method. PCDDs/PCDFs and dl-PCBs concentrations were also reported as toxic equivalent quantity (TEQ) using the toxic equivalent factors (TEFs) provided in Van den Berg et al. (2006).

\subsubsection{PBDEs}

Dust samples were analyzed for 24 PBDEs congeners (namely BDEs $-17,-28,-47,-49,-66,-71,-77,-85,-99,-100,-119,-126$, $-138,-153,-154,-156,-183,-184,-191,-196,-197,-206$, $-207,-209)$. Dried samples were spiked with a mixture of ${ }^{13} \mathrm{C}_{12}$-labeled internal standards (BDEs $-28,-47,-99,-153,-154,-183,-209$ ). Dust samples were extracted in a Soxhlet apparatus (solvents were ultratrace-analyzes quality). Extracts were then cleaned up using concentrated sulfuric acid and then by column chromatography involving activated silica gel and alumina. Recovery yields were determined by the addition of a ${ }^{13} \mathrm{C}_{12}$ labeled recovery standard. PBDEs were analyzed on a gas chromatography coupled to a high resolution mass spectrometer (VG Autospec, Waters). Two isotope masses were measured for each compound. The quantification was performed using the isotope dilution method.

\subsubsection{Quality assurance}

Several parameters were controlled to confirm the reliability of the method for the quantification of the compounds (e.g. retention time,

Table 2

Sampling duration.

\begin{tabular}{llll}
\hline & Sampling period & & Duration (days) \\
\hline Site 1 & $06-04-17$ & $18-10-17$ & 195 \\
& $18-10-17$ & $02-05-18$ & 196 \\
& $02-05-18$ & $13-11-18$ & 195 \\
Site 2 & $13-11-18$ & $18-09-19$ & 309 \\
Site 3 & $05-07-18$ & $31-01-19$ & 210 \\
\hline
\end{tabular}


isotope ratio or recovery yields for ${ }^{13} \mathrm{C}_{12}$-labeled internal standards). A calibration curve (eight-points for chlorinated compounds and tenpoints for PBDEs) was used for the quantification. In parallel to samples, method blanks (including extraction, clean-up and measuring) were analyzed daily. Moreover, in-house quality assurance pool samples were used to control precision and accuracy. Furthermore, certified reference materials were regularly analyzed to check precision and accuracy.

\section{Results and discussion}

\section{1. $P C D D / F s$ and $d l-P C B s$}

The median deposition levels of $\sum$ PCDD/Fs, $\sum$ dl-PCBs and combination of $\sum$ PCDD/Fs and $\sum$ dl-PCBs (PCDD/Fs + dl-PCBs) were 1.9, 4.4 and $6.2 \mathrm{pg} \mathrm{TEQ} / \mathrm{m}^{2}$.day, respectively (ranges: $0.10-5.4,0.49-18.0$, $0.83-23.0$, respectively, Table 3). The Sambre and Meuse Line is an area with high density of population and a relatively high density of industry. Consequently, we cannot exclude that the contamination measured in our samples originates from other sources than shredders. Nevertheless, the amounts of POPs measured in the samples were well correlated with distance between the samplers and the stacks of shredder as well with the position of the gauges relative to the major winds. Moreover, to the best of our knowledge, no other significant source of dust contaminated with POPs were present close to the different samplers. Thereby, in the present discussion, we made the assumption that shredding facilities were the main source of the POPs measured in the fallout dust.

Several investigations assessed the deposition levels of PCDD/Fs and dl-PCBs near different industrial sites (Table 4). In Flanders, the assessment of the atmospheric deposition of these compounds is regularly performed. For instance, during the measurement campaign performed between August 2009 and September 2010, the median deposition level measured in 9 industrial locations (PCDD/Fs + dl-PCBs) was $8.65 \mathrm{pg} \mathrm{TEQ} / \mathrm{m}^{2}$.day which is similar to our observations. Nevertheless, the maximum value measured in Flanders was $316 \mathrm{pg} \mathrm{TEQ} / \mathrm{m}^{2}$. day which is one order of magnitude higher than our highest measurement (Croes et al., 2012). Deposition of PCDD/Fs and PCB 126 were also assessed in the vicinity of 4 shredder sites in Flanders between April 2003 and April 2004 (François et al., 2004). The levels measured were one order of magnitude higher than those observed in Wallonia (average deposition ranging from 16 to $29 \mathrm{pg}$ TEQ of $\mathrm{PCDD} / \mathrm{Fs} / \mathrm{m}^{2}$.day and from 43 to $137 \mathrm{pg}$ TEQ of PCB $126 / \mathrm{m}^{2}$.day. In 2001, European Union adopted a Community strategy for dioxins, furans and PCBs in order to reduce to impact of these pollutants on human health and the environment (Council, the European parliament and the economic and social committee on a community strategy for dioxins, furans and polychlorinated biphenyls, 2002 and the ECJ European Court of Justice, 2008). Thereby, the declining trend of contamination observed in the surrounding area of Belgian shredding facilities may be the result of a reduction of the PCB-content in the materials processed in metal shredders during the last 15 years and/or the consequence of the improvement of the regulations imposed to the shredder plant operator. This declining trend was also highlighted by Bruckmann et al. (2013) who assessed the deposition of PCDD/Fs in four urban sites and one industrial site in Germany. They showed that the deposition levels declined from between 20 and $35 \mathrm{pg}$ $\mathrm{TEQ} / \mathrm{m}^{2}$.day in 1992 to between 5 and $10 \mathrm{pg} \mathrm{TEQ} / \mathrm{m}^{2}$.day in 2011 in urban site and from $363 \mathrm{pg} \mathrm{TEQ} / \mathrm{m}^{2}$.day in 1998 to approximately $30 \mathrm{pg}$ $\mathrm{TEQ} / \mathrm{m}^{2}$.day in 2011 in the industrial site. Fang et al. (2011) measured

Table 3

Depositional fluxes of POPs in bulk atmospheric deposition in shredding sites.

\begin{tabular}{|c|c|c|c|c|c|c|c|c|c|c|}
\hline & $\begin{array}{l}\sum \mathrm{PCDD} / \mathrm{Fs} \\
\text { (pg TEQ } / \mathrm{m}^{2} . \\
\text { day) }\end{array}$ & $\begin{array}{l}\sum \mathrm{dl}- \\
\mathrm{PCBs} \\
\left(\mathrm{ng} / \mathrm{m}^{2}\right. \\
\text { day) }\end{array}$ & $\begin{array}{l}\sum \mathrm{dl}-\mathrm{PCBs} \\
\text { (pg TEQ/ } \\
\mathrm{m}^{2} \text {.day) }\end{array}$ & $\begin{array}{l}\sum \mathrm{PCDD} / \mathrm{Fs}+ \\
\sum \mathrm{dl}-\mathrm{PCBs}(\mathrm{pg} \\
\mathrm{TEQ} / \mathrm{m}^{2} . \text { day) }\end{array}$ & $\begin{array}{l}\sum 7 \text { indicator } \\
\text { PCBs }\left(\mathrm{ng} / \mathrm{m}^{2} \text {. }\right. \\
\text { day) }\end{array}$ & $\begin{array}{l}\sum \text { PCBs DIN } \\
\text { (indicator } \\
\text { without PCB 118) } \\
\text { (ng } / \mathrm{m}^{2} \text {.day) }\end{array}$ & $\begin{array}{l}5 \times \sum 6 \text { PCBs } \\
\text { DIN (= total } \\
\text { PCBs) } \\
\left(\mathrm{ng} / \mathrm{m}^{2} \text {.day) }\right.\end{array}$ & $\begin{array}{l}\text { PBDE } 47 \\
\left(\mathrm{ng} / \mathrm{m}^{2}\right. \\
\text { day) }\end{array}$ & $\begin{array}{l}\text { PBDE } 99 \\
\left(\mathrm{ng} / \mathrm{m}^{2} \text {. }\right. \\
\text { day) }\end{array}$ & $\begin{array}{l}\text { PBDE } 209 \\
\left(\mathrm{ng} / \mathrm{m}^{2} .\right. \\
\text { day) }\end{array}$ \\
\hline \multicolumn{11}{|c|}{ Site 1 (December 2017) } \\
\hline Sampler 1 & - & 1.3 & 0.5 & - & 4.4 & 3.8 & 19.0 & 0.8 & 2.8 & 53.5 \\
\hline Sampler 2 & - & 8.3 & 3.8 & - & 22.9 & 19.2 & 95.8 & 3.5 & 11.0 & 118.0 \\
\hline Sampler 3 & - & 18.3 & 7.4 & - & 49.8 & 41.8 & 209.2 & 6.2 & 21.7 & 113.0 \\
\hline Sampler 4 & - & 5.2 & 2.8 & - & 17.1 & 14.8 & 73.9 & 2.1 & 7.4 & 51.4 \\
\hline \multicolumn{11}{|c|}{ Site 1 (June 2018) } \\
\hline Sampler 1 & 1.1 & 18.3 & 3.8 & 5.0 & 62.9 & 54.3 & 271.6 & 4.9 & 12.0 & 231.0 \\
\hline Sampler 2 & 3.3 & 40.6 & 6.4 & 9.7 & 171.6 & 151.3 & 756.3 & 19.4 & 36.7 & 523.5 \\
\hline Sampler 3 & 4.4 & 42.0 & 7.7 & 12.0 & 191.9 & 170.9 & 854.6 & 12.4 & 29.8 & 886.1 \\
\hline Sampler 4 & 0.9 & 10.3 & 3.4 & 4.4 & 39.4 & 34.0 & 170.2 & $<3.1$ & $<6.2$ & $<154.2$ \\
\hline \multicolumn{11}{|c|}{ Site 1 (December 2018) } \\
\hline Sampler 1 & 1.0 & 4.6 & 1.9 & 3.0 & 19.7 & 17.4 & 87.2 & 3.0 & 7.6 & 192.3 \\
\hline Sampler 2 & 3.9 & 23.6 & 11.0 & 14.9 & 85.0 & 73.8 & 368.8 & 8.9 & 22.9 & 801.8 \\
\hline Sampler 3 & 5.4 & 53.4 & 16.9 & 22.3 & 190.7 & 164.6 & 822.9 & 11.9 & 27.5 & 1158.9 \\
\hline Sampler 4 & 2.6 & 26.7 & 10.7 & 13.4 & 93.3 & 80.2 & 401.0 & 4.9 & 12.0 & 630.0 \\
\hline Sampler 5 & 0.3 & 5.0 & 1.7 & 1.9 & 19.8 & 17.4 & 87.0 & $<4.4$ & $<8.9$ & $<222.0$ \\
\hline \multicolumn{11}{|c|}{ Site 1 (September 2019) } \\
\hline Sampler 1 & 0.4 & 8.4 & 2.3 & 2.8 & 27.0 & 22.7 & 113.5 & 3.2 & 6.9 & 166.6 \\
\hline Sampler 2 & 2.2 & 27.3 & 6.3 & 8.5 & 87.5 & 73.9 & 369.7 & 7.0 & 16.0 & 375.5 \\
\hline Sampler 3 & 2.4 & 42.2 & 8.4 & 10.7 & 132.3 & 110.1 & 550.7 & 18.6 & 41.7 & 662.4 \\
\hline Sampler 4 & 1.5 & 26.7 & 4.8 & 6.3 & 57.0 & 49.5 & 247.7 & 6.3 & 14.1 & 307.9 \\
\hline Sampler 5 & 0.1 & 2.2 & 0.7 & 0.8 & 7.1 & 6.0 & 30.2 & $<2.4$ & $<4.7$ & $<117.5$ \\
\hline \multicolumn{11}{|c|}{ Site 2 (April 2019) } \\
\hline Sampler 1 & 0.9 & 9.0 & 3.2 & 4.1 & 37.4 & 33.1 & 165.4 & 3.2 & 6.4 & 267.3 \\
\hline Sampler 2 & 4.9 & 53.0 & 18.0 & 23.0 & 273.4 & 249.2 & 1246.0 & 18.0 & 33.8 & 1012.8 \\
\hline Sampler 3 & 2.5 & 13.4 & 2.1 & 4.6 & 55.5 & 49.1 & 245.4 & 3.1 & 6.2 & 240.3 \\
\hline Sampler 4 & 0.2 & 4.5 & 1.8 & 2.0 & 16.3 & 14.1 & 70.5 & 2.0 & 3.1 & 89.2 \\
\hline \multicolumn{11}{|c|}{ Site 3 (April 2019) } \\
\hline Sampler 1 & 2.2 & 29.1 & 8.6 & 10.7 & 110.1 & 100.3 & 501.7 & 3.4 & $<6.2$ & 431.2 \\
\hline Sampler 2 & 1.7 & 15.1 & 4.2 & 5.9 & 63.2 & 55.2 & 276.0 & 3.4 & $<6.7$ & 274.0 \\
\hline Sampler 3 & 2.7 & 24.0 & 8.1 & 10.8 & 93.7 & 81.6 & 408.0 & 4.0 & 7.4 & 355.7 \\
\hline Sampler 4 & 1.4 & 12.5 & 4.6 & 6.0 & 51.4 & 45.3 & 226.6 & 3.5 & 6.4 & 229.0 \\
\hline Minimum & 0.1 & 1.3 & 0.5 & 0.8 & 4.4 & 3.8 & 19.0 & $<\mathrm{LOQ}$ & $<\mathrm{LOQ}$ & $<\mathrm{LOQ}$ \\
\hline Maximum & 5.4 & 53.4 & 18.0 & 23.0 & 273.4 & 249.2 & 1246.0 & 19.4 & 41.7 & 1158.9 \\
\hline Median & 1.9 & 16.7 & 4.4 & 6.2 & 56.3 & 49.3 & 246.5 & 3.5 & 7.5 & 253.8 \\
\hline
\end{tabular}


Table 4

Comparison of $\sum$ PCDD/Fs $+\sum$ dl-PCBs deposition fluxes in the vicinity of shredding sites in Belgium with those reported in the literature.

\begin{tabular}{|c|c|c|c|c|}
\hline Ref. & Location & Years & $\begin{array}{l}\text { Median } \\
\text { (pg TEQ/ } \\
\mathrm{m}^{2} \text {.day) }\end{array}$ & $\begin{array}{l}\text { Maximum } \\
\text { (pg TEQ/m². } \\
\text { day) }\end{array}$ \\
\hline & Industrial & & & \\
\hline Present study & $\begin{array}{l}\text { Vicinity of } \\
\text { shredding facilities } \\
\text { (Wallonia, } \\
\text { Belgium) }\end{array}$ & 2017-2019 & 6.2 & 23 \\
\hline $\begin{array}{l}\text { Croes et al. } \\
\text { (2012) }\end{array}$ & $\begin{array}{l}\text { Industrial locations } \\
\text { (Flanders, } \\
\text { Belgium) }\end{array}$ & 2009-2010 & 8.65 & 316 \\
\hline $\begin{array}{l}\text { François et al. } \\
\text { (2004) }\end{array}$ & $\begin{array}{l}\text { Vicinity of } \\
\text { shredding facilities } \\
\text { (Flanders, } \\
\text { Belgium) }\end{array}$ & 2003-2004 & $16-29^{\mathrm{a}, \mathrm{b}}$ & $54^{\mathrm{b}}$ \\
\hline \multirow{2}{*}{$\begin{array}{l}\text { Bruckmann } \\
\text { et al. } \\
\text { (2013) }\end{array}$} & $\begin{array}{l}\text { Industrial or urban } \\
\text { sites (Germany) }\end{array}$ & 1992 & $20-35^{\mathrm{a}}$ & - \\
\hline & & 2011 & $5-10^{\mathrm{a}}$ & - \\
\hline \multirow[t]{2}{*}{$\begin{array}{l}\text { Fang et al. } \\
\quad(2011)\end{array}$} & $\begin{array}{l}\text { Steel complex } \\
\text { (South Korea) }\end{array}$ & 2008-2009 & 5.2 & 13.25 \\
\hline & $\begin{array}{l}\text { Steel complex } \\
\text { residential } \\
\text { surrounding area } \\
\text { (South Korea) } \\
\text { Non-industrial }\end{array}$ & 2008-2009 & 3.1 & 6.7 \\
\hline $\begin{array}{l}\text { Croes et al. } \\
\text { (2012) }\end{array}$ & $\begin{array}{l}\text { Residential and } \\
\text { agricultural } \\
\text { locations (Flanders, } \\
\text { Belgium) }\end{array}$ & 2009-2010 & 11.5 & 214 \\
\hline $\begin{array}{l}\text { Fang et al. } \\
\text { (2011) }\end{array}$ & $\begin{array}{l}\text { Semi-rural area } \\
\text { (South Korea) }\end{array}$ & 2008-2009 & 2.8 & 12.1 \\
\hline $\begin{array}{l}\text { Bruckmann } \\
\text { et al. } \\
\text { (2013) }\end{array}$ & $\begin{array}{l}\text { Rural station } \\
\text { (Germany) }\end{array}$ & 2011 & $5-10^{\mathrm{a}}$ & - \\
\hline $\begin{array}{l}\text { Hovmand } \\
\text { et al. } \\
\text { (2007) }\end{array}$ & $\begin{array}{l}\text { Forest districts } \\
\text { (Germany, } \\
\text { Denmark and } \\
\text { Sweden) }\end{array}$ & 2002-2004 & $1.1^{\mathrm{a}, \mathrm{b}}$ & - \\
\hline
\end{tabular}

${ }^{\mathrm{a}}$ Mean deposition level flux.

${ }^{\mathrm{b}} \sum \mathrm{PCDD} / \mathrm{Fs}$ only.

between January 2008 and May 2009, the deposition levels of PCDD/Fs (not dl-PCBs) in the vicinity of a steel complex and in a surrounding residential area (South Korea). The levels measured were slightly higher than ours (median $=5.2$ and $3.1 \mathrm{pg} \mathrm{TEQ} / \mathrm{m}^{2}$.day in steel complex and in the residential area, respectively). Globally, the levels measured in the present study seems to be similar or lower compared to the levels observed in the vicinity of other industrial plant. This relative low level, particularly relative to the level determined in the area surrounding metal shedder in Flanders may be the consequence of the declining trends observed in the contamination of the environment by PCDD/Fs.

Surprisingly, the background levels measured in non-industrial areas were also reported to be sometimes quite high (Table 4). During the investigation of Croes et al. (2012) in Flanders, deposition levels were also measured in residential and agricultural locations and were relatively high ( median $=11.5 \mathrm{pg}$ TEQ $/ \mathrm{m}^{2}$.day and $\mathrm{max}=214 \mathrm{pg} \mathrm{TEQ} / \mathrm{m}^{2}$. day). Fang et al. (2011) observed levels of deposition in semi-rural area distant from the steel complex surprisingly similar to those observed in the industrial area (median $=2.8 \mathrm{pg} \mathrm{TEQ} / \mathrm{m}^{2}$.day). The average level of PCDD/Fs deposition measured by Hovmand et al. (2007) between February 2002 and February 2004 in forest districts located in northern Germany, in Denmark and in Sweden was $1.1 \mathrm{pg}$ TEQ/ $\mathrm{m}^{2}$.day. Similarly, Bruckmann et al. (2013) reported levels ranging from 5 to $10 \mathrm{pg}$ $\mathrm{TEQ} / \mathrm{m}^{2}$.day in a rural station situated more than $100 \mathrm{~km}$ away from dense urban area and they observed that these levels were similar to those measured in the urban and industrial area during the same sampling period (2011). Bruckmann et al. suggested that the measures to reduce $\mathrm{PCDD} / \mathrm{Fs}$ emission are successful since the emission measured in urban and industrial area reached background levels measured in remote area. We agree with this affirmation since the levels we measured were similar to those measured in several non-urban/non-industrial area. Nevertheless, even in remote area distant from industrial activities, deposition fluxes remains relatively high, which is the consequence of the capability of POPs to distribute widely in the environment notably by air transportation and of their remarkable resistance to degradation in the environment.

\subsection{Non-dioxin-like PCBs}

Even if non-dl PCBs don't bind to AhR, they may cause health adverse effects (for instance, thyroid and reproductive effects) (Bergman et al., 2013; Boas et al., 2012). Among non-dl PCBs, we measured PCBs $-28,-52,-101,-138,-153$ and -180 . According to the European Guideline DIN EN 12766-2, 2001, the sum of these 6 PCBs multiplied by a factor 5 may be considered as a good estimation of the total PCBs contamination in the samples. We used thus $5 \times \sum 6$ PCBs DIN as an approximation of the total PCBs deposition fluxes (total PCBs were reported as " $5 \times \sum 6$ PCBs DIN (= total PCBs)" in Table 3 ). The median deposition level of total PCBs was $247 \mathrm{ng} / \mathrm{m}^{2}$.day (range: 19-1246 $\mathrm{ng} / \mathrm{m}^{2}$.day). To the best of our knowledge, few recent data about the deposition level of non-dl PCBs are available (Table 5). Indeed for instance, these compounds are not considered during the regular monitoring campaigns performed in Flanders (Croes et al., 2012). The levels highlighted in the present study were among the highest reported in the literature although one order of magnitude higher deposition rates (mean level: $4730 \mathrm{ng} / \mathrm{m}^{2}$.day) were measured by Lee et al. (1996) in the center of Tainan City (Taiwan) in 1994. Taiwan is characterized by a high population and industry density, moreover PCBs were banned from the island progressively during the 80's and this study were performed few years later, in 1994. These elements may explain the tremendous deposition fluxes reported by Lee et al. Two fold higher levels were also observed in a Turkish village located in the vicinity of several heavy industries between 2004 and 2005 (mean levels: 349 and $469 \mathrm{ng} / \mathrm{m}^{2}$.

Table 5

Comparison of total PCBs deposition fluxes in the vicinity of shredding sites in Belgium with those reported in the literature.

\begin{tabular}{|c|c|c|c|c|}
\hline Ref. & Location & Years & $\begin{array}{l}\text { Median } \\
\left(\mathrm{ng} / \mathrm{m}^{2} .\right. \\
\text { day) }\end{array}$ & $\begin{array}{l}\text { Maximum } \\
\left(\mathrm{ng} / \mathrm{m}^{2} \text {.day) }\right.\end{array}$ \\
\hline Present study & $\begin{array}{l}\text { Vicinity of } \\
\text { shredding facilities } \\
\text { (Belgium) }\end{array}$ & 2017-2019 & 246.5 & 1246.0 \\
\hline $\begin{array}{l}\text { Lee et al. } \\
\text { (1996) }\end{array}$ & $\begin{array}{l}\text { Tawain City center } \\
\text { (Taiwan) }\end{array}$ & 1994 & $4730^{\mathrm{a}}$ & 6790 \\
\hline \multirow[t]{2}{*}{$\begin{array}{l}\text { Bozlaker et al. } \\
\text { (2008) }\end{array}$} & \multirow[t]{2}{*}{$\begin{array}{l}\text { Vicinity of heavy } \\
\text { industries (Turkey) }\end{array}$} & $\begin{array}{l}\text { Summer } \\
2004\end{array}$ & $349^{\mathrm{a}}$ & - \\
\hline & & $\begin{array}{l}\text { Winter } \\
2005\end{array}$ & $469^{a}$ & - \\
\hline $\begin{array}{l}\text { Tasdemir and } \\
\text { Holsen } \\
(2005)\end{array}$ & Chicago (USA) & 2005 & $240^{\mathrm{a}}$ & - \\
\hline $\begin{array}{l}\text { Granier and } \\
\text { Chevreuil } \\
\text { (1997) }\end{array}$ & $\begin{array}{l}\text { Urban area of Paris } \\
\text { (France) }\end{array}$ & 1989 & $79.5^{\mathrm{a}}$ & - \\
\hline $\begin{array}{l}\text { Park et al. } \\
\text { (2002) }\end{array}$ & $\begin{array}{l}\text { Corpus Christi Bay } \\
\text { (Texas, USA) }\end{array}$ & 1998-1999 & $2.7^{\mathrm{a}}$ & - \\
\hline \multirow{3}{*}{$\begin{array}{l}\text { de Souza } \\
\text { Pereira } \\
\text { et al. } \\
(2007)\end{array}$} & Highly & 2003-2004 & 43.7 & 313.7 \\
\hline & $\begin{array}{l}\text { industrialized area } \\
\text { (Brasil) }\end{array}$ & & & \\
\hline & $\begin{array}{l}\text { Itatiaia National } \\
\text { Park (Brasil) }\end{array}$ & 2003-2004 & 18.2 & 42.8 \\
\hline $\begin{array}{l}\text { Qu et al. } \\
\text { (2019) }\end{array}$ & Campania (Italy) & 2015-2017 & 0.2 & $>1$ \\
\hline
\end{tabular}

${ }^{\mathrm{a}}$ Mean deposition flux. 
day in summer and winter respectively) (Bozlaker et al., 2008). On the other hand, our measurements were similar to those reported by Tasdemir and Holsen (2005) in Chicago between June and October 2005 (mean level: $240 \mathrm{ng} / \mathrm{m}^{2}$.day) but were higher than those observed in the urban area of Paris (France) in 1989 (mean level: $79.5 \mathrm{ng} / \mathrm{m}^{2}$.day) (Granier and Chevreuil, 1997), in the Corpus Christi Bay (Texas, USA) between August 1998 and September 1999 (mean level: $2.7 \mathrm{ng} / \mathrm{m}^{2}$.day) (Park et al., 2002), in Volta Redonda (an highly industrialized region in Brasil) (deposition levels ranging from 16.9 to $313.7 \mathrm{ng} / \mathrm{m}^{2}$.day) and in the Itatiaia National Park (Brasil) (range: $8.3-81.6 \mathrm{ng} / \mathrm{m}^{2}$.day) in 2003-2004 (de Souza Pereira et al., 2007) or during the recent investigations (sampling campaign lasted from July 2015 to March 2017) performed in Campania region (Italy) (median level of the sum of 18 PCBs: $0.2 \mathrm{ng} / \mathrm{m}^{2}$.day) (Qu et al., 2019). Note that the authors of the studies discussed above each used a different method to measure/estimate total PCBs (only de Souza Pereira et al., 2007 referred to $5 \times$ $\sum 6$ PCBs DIN like us) which may hamper the comparisons.

\subsection{PBDEs}

Because of the high concentrations of PCBs and PCDD/Fs highlighted in the dust, we had to dilute the samples before quantification. Unfortunately, doing this, we also diluted PBDEs, consequently, only PBDEs $-47,-99$ and -209 were quantified above the LOQ in most of the samples. The concentration measured for these compounds were reported in Table 3. Notwithstanding this sensitivity issue, the concentrations observed in the present study were among the highest reported in the literature (Table 6 presents BDE 209 concentrations measured in different studies). The median deposition level of PBDE $209\left(254 \mathrm{ng} / \mathrm{m}^{2}\right.$.

Table 6

Comparison of PBDE 209 deposition fluxes in the vicinity of shredding sites in Belgium with those reported in the literature.

\begin{tabular}{|c|c|c|c|c|}
\hline Ref. & Location & Years & $\begin{array}{l}\text { Median } \\
\text { (ng/m². } \\
\text { day) }\end{array}$ & $\begin{array}{l}\text { Maximum } \\
\left(\mathrm{ng} / \mathrm{m}^{2} \text {.day) }\right.\end{array}$ \\
\hline $\begin{array}{r}\text { Present } \\
\text { study }\end{array}$ & $\begin{array}{l}\text { Vicinity of } \\
\text { shredding facilities } \\
\text { (Belgium) }\end{array}$ & 2017-2019 & 253.8 & 1158.9 \\
\hline \multirow{4}{*}{$\begin{array}{l}\text { Arellano } \\
\text { et al. } \\
\text { (2014) }\end{array}$} & $\begin{array}{l}\text { High mountain site } \\
\text { (Austria) }\end{array}$ & 2004-2006 & $2.4^{\mathrm{a}}$ & 8.2 \\
\hline & $\begin{array}{l}\text { High mountain site } \\
\text { (Spain) }\end{array}$ & 2004-2006 & $3.2^{\mathrm{a}}$ & 13.6 \\
\hline & $\begin{array}{l}\text { High mountain sites } \\
\text { (Slovakia) }\end{array}$ & 2004-2006 & $5.4^{\mathrm{a}}$ & 23.5 \\
\hline & $\begin{array}{l}\text { High mountain sites } \\
\text { (Scotland) }\end{array}$ & 2004-2006 & $4^{a}$ & 10.6 \\
\hline $\begin{array}{l}\text { Zhan et al. } \\
\text { (2019) }\end{array}$ & $\begin{array}{l}\text { Mountain area } \\
\text { (China) }\end{array}$ & 2012-2013 & $0.45^{\mathrm{a}}$ & 2.4 \\
\hline \multirow{3}{*}{$\begin{array}{l}\text { ter Schure } \\
\text { et al. } \\
(2004)\end{array}$} & $\begin{array}{l}\text { Rural region } \\
\text { (Sweden) }\end{array}$ & 2001-2002 & 4.3 & - \\
\hline & $\begin{array}{l}\text { Municipal solid } \\
\text { waste treatment } \\
\text { plant (Sweden) }\end{array}$ & 2001-2002 & 63.8 & - \\
\hline & $\begin{array}{l}\text { Asphalt industry } \\
\text { (Sweden) }\end{array}$ & 2001-2002 & 14.7 & - \\
\hline \multirow{2}{*}{$\begin{array}{l}\text { Cetin and } \\
\text { Odabasi } \\
(2007)\end{array}$} & $\begin{array}{l}\text { Suburban district of } \\
\text { Izmir (Turkey) }\end{array}$ & 2004-2005 & $49.4^{\mathrm{a}}$ & - \\
\hline & $\begin{array}{l}\text { Urban district } \\
\text { (Turkey) }\end{array}$ & 2004-2005 & $107.5^{\mathrm{a}}$ & - \\
\hline \multirow[t]{3}{*}{$\begin{array}{l}\text { Tian et al. } \\
\text { (2011) }\end{array}$} & $\begin{array}{l}\text { Urban site in city of } \\
\text { Guangzhou (China) }\end{array}$ & 2007-2008 & $203^{\mathrm{a}}$ & - \\
\hline & $\begin{array}{l}\text { e-waste recycling } \\
\text { area (China) }\end{array}$ & 2007-2008 & $394^{\mathrm{a}}$ & - \\
\hline & & 2007-2008 & $11.8^{\mathrm{a}}$ & - \\
\hline $\begin{array}{l}\text { Li et al. } \\
\text { (2010) }\end{array}$ & $\begin{array}{l}\text { University of } \\
\text { Guangzhou }\end{array}$ & 2003-2004 & 2080 & 6000 \\
\hline
\end{tabular}

${ }^{\mathrm{a}}$ Mean deposition flux. day) in the present study was 2 or 3 order of magnitude higher than those determined in sites remote from densely populated or heavily industrialized area: Arellano et al. (2014) reported mean depositional fluxes of PBDE 209 ranging from 2.4 to $5.4 \mathrm{ng} / \mathrm{m}^{2}$.day measured in four high mountain regions of Europe; a total deposition flux of $0.45 \mathrm{ng} / \mathrm{m}^{2}$. day was observed in an isolated mountain area located in central China (Zhan et al., 2019); and, in a rural region of Sweden, the median deposition level of PBDE 209 was $4.3 \mathrm{ng} / \mathrm{m}^{2}$.day (ter Schure et al., 2004). The deposition fluxes of PBDE 209 observed during our campaign were also higher than those measured in suburban and urban districts of Izmir (Turkey) (average levels: 49.4 and $107.5 \mathrm{ng} / \mathrm{m}^{2}$.day respectively) (Cetin and Odabasi, 2007) or in the vicinity of a municipal solid waste treatment plant (median deposition flux: $63.8 \mathrm{ng} / \mathrm{m}^{2}$.day) and an asphalt industry (median deposition flux: $14.7 \mathrm{ng} / \mathrm{m}^{2}$.day) located in Sweden (ter Schure et al., 2004). Finally, similar or higher levels of deposition were reported in several locations in China, for instance, Tian et al. (2011) measured an average deposition level of $203 \mathrm{ng} / \mathrm{m}^{2}$.day in an urban site in the city of Guangzhou and a mean deposition flux of 394 $\mathrm{ng} / \mathrm{m}^{2}$.day in the vicinity of an e-waste recycling area. To the best of our knowledge, the highest deposition flux measured $\left(2080 \mathrm{ng} / \mathrm{m}^{2}\right.$.day) was observed on the rooftop of the Sun Yet-Sen University of Guangzhou between December 2003 and December 2004 (Li et al., 2010).

PBDEs were progressively banned in Europe: deca-BDE, a PBDE mixture containing more than $97 \%$ of PBDE 209 was the last PBDE mixture regulated and was prohibited in 2008 (ECJ European Court of Justice, 2008). That suggests that we can hope to observe a reduction of the emission in next years. Nevertheless, as illustrated by the case of PCBs (banned in Europe since the 70's), several years or even decades will be necessary to observe a decrease in deposition fluxes to acceptable levels. Health concerns about this family of compounds will thus remain for many years.

\subsection{Human exposure and health risks}

The aim of the present study was not to assess the impact of this pollution on workers' and surrounding population's health. Nevertheless, given the high deposition levels of PCBs and PBDEs measured in this study, we have to wonder about the health risks associated with this exposure.

First, we could suspect that workers in these shredder facilities are exposed to a significant amount of pollutants. As mentioned above, the level of PBDEs deposition measured in our investigation was similar to those reported in the vicinity of e-waste recycling area. Several studies reported than the high PBDEs levels in the atmosphere of such facilities induce an important exposure by inhalation or dust ingestion to PBDEs but also to PCBs for the e-waste workers exceeding the levels considered as safe (Chen et al., 2011; Liu et al., 2019; Zhang et al., 2019). We could thus expect that shredder facility workers experience similar concerning exposure.

Secondly, as demonstrated by the deposition levels measured a few hundred meters away from the shredder facilities, the population living in the vicinity must also be considered at risk. Total PCBs contamination provide a good example of the health risk posed by pollutant atmospheric deposition to surrounding population, especially to children. Because of their hand-to-mouth behavior, children are particularly exposed to pollutants via dust/soil ingestion. According to the EPA report (2017), median daily amount of dust and soil ingested by children range from $40 \mathrm{mg}$ to $90 \mathrm{mg}$ depending on age and the $\mathrm{P} 95$ may be as high as $200 \mathrm{mg}$ /day. The total PCBs concentrations measured in fallout dust in the present study ranged from $282.8 \mu \mathrm{g} / \mathrm{kg} \mathrm{dw}$ to $14,040 \mu \mathrm{g} / \mathrm{kg}$ $\mathrm{dw}$ which represent a potential median daily intake of $11.3 \mathrm{ng} /$ day (P95 $=56.6 \mathrm{ng} /$ day $)$ and $561 \mathrm{ng} /$ day $(\mathrm{P} 95=2808 \mathrm{ng} /$ day $)$ respectively. The Agency for Toxic Substances and Disease Registry established a tolerable daily intake (TDI) of total PCBs at $20 \mathrm{ng} /$ day $\times \mathrm{kg}$ body weight (ATSDR, 2000; Grassi et al., 2010). In the worst scenario (daily dust/soil ingestion: $200 \mathrm{mg}$, total PCBs level: $14,040 \mu \mathrm{g} / \mathrm{kg} \mathrm{dw}$ and fallout dust 
contributing for $100 \%$ to the dust/soil ingested), the daily intake (2808 $\mathrm{ng} /$ day) is more than 10 fold higher than TDI for a child of $12 \mathrm{~kg}$ (240 $\mathrm{ng}$ /day). Our evaluation is obviously rough because the contribution of fallout dust to dust/soil ingested is unknown and certainly not equal to $100 \%$ and because $5 \times \sum 6$ PCBs DIN is only an estimation of total PCBs, nevertheless, we can reasonably assume that children living in the surrounding area are exposed to inacceptable level of PCBs through dust/soil ingestion. Moreover, to evaluate contamination originating from fallout deposition, we have also to consider dust inhalation and food contamination, indeed, the dust emitted by the shredding industry can also contaminate the vegetable garden or the home-produced hen's eggs consumed in the neighborhood. Undoubtedly, surrounding population contamination should be assessed more in depth.

Moreover, to the best of our knowledge, no epidemiological studies assessed the association between atmospheric exposure to POPs and health parameters. However, several investigations showed that serum levels of PBDEs were associated with many health alterations; for instance, thyroid disorders (Chevrier et al., 2010; Turyk et al., 2008), immunologic and hematologic defects (Leijs et al., 2009) or neurodevelopmental impairments in children (Ji et al., 2019), while serum levels of PCBs were also associated with thyroid dysfunction (Dufour et al., 2020; Langer et al., 2007), with hypertension and cardiovascular diseases (Raffetti et al., 2018), with breast cancers (Charlier et al., 2004), with diabetes (Han et al., 2020), etc.

Consequently, in order to confirm the health concerns potentially associated with the shredders' emissions, the next step of the investigation should be the assessment of the serum concentration of PBDEs and PCBs in the exposed population.

\section{Conclusion}

Shredding facilities use processes and materials that promote the release and the dispersion of dusts containing hazardous pollutants. In the present study, we measured the levels of PCDD/Fs, PCBs and PBDEs present in the deposition dust samples collected in the environment of the shredders. For several compounds, we highlighted levels higher than those observed in remote, rural or even some urban areas around the world and similar to those measured in other heavily industrialized areas. We strongly suspect that this pollution is originated from the shredding facilities. Consequently, we presume that the health of the workers but also of the population living at proximity of such facilities can be impacted by a high exposure to pollutants. Thus, we recommend the planning and the implementation of biomonitoring campaigns involving the shredding facility workers and neighboring population.

\section{Credit authors}

Patrice Dufour: Formal analysis, Writing - original draft. Catherine Pirard: Writing - review \& editing. Geoffrey Ortegat: Writing - review \& editing, Investigation. Jean-Marc Brouhon: Writing - review \& editing, Conceptualization, Methodology, Investigation. Corinne Charlier: Writing - review \& editing, Supervision.

\section{Declaration of competing interest}

The authors declare that they have no known competing financial interests or personal relationships that could have appeared to influence the work reported in this paper.

\section{References}

Agency for Toxic Substances and Disease Registry, 2000. Toxicological Profile for Polychlorinated Biphenyls (PCBs).

Arellano, L., Fernández, P., López, J.F., Rose, N.L., Nickus, U., Thies, H., Stuchlik, E., Camarero, L., Catalan, J., Grimalt, J.O., 2014. Atmospheric deposition of polybromodiphenyl ethers in remote mountain regions of Europe. Atmos. Chem. Phys. 14, 4441-4457. https://doi.org/10.5194/acp-14-4441-2014.
Baan, R., Grosse, Y., Straif, K., Secretan, B., El Ghissassi, F., Bouvard, V., BenbrahimTallaa, L., Guha, N., Freeman, C., Galichet, L., Cogliano, V., 2009. A review of human carcinogens-Part F: chemical agents and related occupations. Lancet Oncol. 10, 1143-1144. https://doi.org/10.1016/S1470-2045(09)70358-4.

Bergman, Á., Heindel, J.J., Jobling, S., Kidd, K.A., Zoeller, R.T., 2013. State of the Science of Endocrine Disrupting Chemicals 2012. WHO.

Boas, M., Feldt-Rasmussen, U., Main, K.M., 2012. Thyroid effects of endocrine disrupting chemicals. Molecular and Cellular Endocrinology, Health Impacts Of Endocrine Disrupters 355, 240-248. https://doi.org/10.1016/j.mce.2011.09.005.

Bozlaker, A., Odabasi, M., Muezzinoglu, A., 2008. Dry deposition and soil-air gas exchange of polychlorinated biphenyls (PCBs) in an industrial area. Environ. Pollut. 156, 784-793. https://doi.org/10.1016/j.envpol.2008.06.008.

Bruckmann, P., Hiester, E., Klees, M., Zetzsch, C., 2013. Trends of PCDD/F and PCB concentrations and depositions in ambient air in Northwestern Germany. Chemosphere 93, 1471-1478. https://doi.org/10.1016/j. chemosphere.2013.07.029.

Cahill, T.M., Groskova, D., Charles, M.J., Sanborn, J.R., Denison, M.S., Baker, L., 2007. Atmospheric concentrations of polybrominated diphenyl ethers at near-source sites. Environ. Sci. Technol. 41, 6370-6377. https://doi.org/10.1021/es070844j.

Cetin, B., Odabasi, M., 2007. Particle-Phase dry deposition and Air-Soil gas-exchange of polybrominated diphenyl ethers (PBDEs) in Izmir, Turkey. Environ. Sci. Technol. 41, 4986-4992. https://doi.org/10.1021/es070187v.

Charlier, C.J., Albert, A.I., Zhang, L., Dubois, N.G., Plomteux, G.J., 2004. Polychlorinated biphenyls contamination in women with breast cancer. Clin. Chim. Acta 347, 177-181. https://doi.org/10.1016/j.cccn.2004.04.025.

Chen, D., Bi, X., Liu, M., Huang, B., Sheng, G., Fu, J., 2011. Phase partitioning, concentration variation and risk assessment of polybrominated diphenyl ethers (PBDEs) in the atmosphere of an e-waste recycling site. Chemosphere 82, 1246-1252. https://doi.org/10.1016/j.chemosphere.2010.12.035.

Chevrier, J., Harley, K.G., Bradman, A., Gharbi, M., Sjödin, A., Eskenazi, B., 2010. Polybrominated diphenyl ether (PBDE) flame retardants and thyroid hormone during pregnancy. Environ. Health Perspect. 118, 1444-1449. https://doi.org/ 10.1289/ehp.1001905.

Council, the European parliament and the economic and social committee on a community strategy for dioxins, furans and polychlorinated biphenyls, 2002. Communication from the commission to the Council, the European parliament and the economic and social committee on a community strategy for dioxins, furans and polychlorinated biphenyls (COM (2001) 593 final), 17.11 Official Journal of the European Communities C322, 2-18. http://europa.eu.int/eur-lex/pri/en/oj/dat/200 1/c322/c32220011117en00020018.pdf.

Croes, K., Vandermarken, T., Van Langenhove, K., Elskens, M., Desmedt, M., Roekens, E., Denison, M.S., Van Larebeke, N., Baeyens, W., 2012. Analysis of PCDD/Fs and dioxin-like PCBs in atmospheric deposition samples from the Flemish measurement network: correlation between the CALUX bioassay and GC-HRMS. Chemosphere 88 , 881-887. https://doi.org/10.1016/j.chemosphere.2012.03.097.

de Souza Pereira, M., Heitmann, D., Reifenhäuser, W., Meire, R.O., Santos, L.S., Torres, J. P.M., Malm, O., Körner, W., 2007. Persistent organic pollutants in atmospheric deposition and biomonitoring with Tillandsia usneoides (L.) in an industrialized area in Rio de Janeiro state, southeast Brazil - Part II: PCB and PAH. Chemosphere, Halogenated Persistent Organic Pollutants Dioxin 67, 1736-1745. https://doi.org/ 10.1016/j.chemosphere.2006.05.141, 2004.

DIN EN 12766-2, 2001. Bestimmung von PCBs und verwandten Produkten, Teil 2: berechnung des Gehaltes an polychlorierten Biphenylen (PCB). Beuth Verlag, Berlin, Germany (n.d).

Dingemans, M.M.L., van den Berg, M., Westerink, R.H.S., 2011. Neurotoxicity of brominated flame retardants: (In)direct effects of parent and hydroxylated polybrominated diphenyl ethers on the (developing) nervous system. Environ. Health Perspect. 119, 900-907. https://doi.org/10.1289/ehp.1003035.

Dufour, P., Pirard, C., Petrossians, P., Beckers, A., Charlier, C., 2020. Association between mixture of persistent organic pollutants and thyroid pathologies in a Belgian population. Environ. Res. 181, 108922. https://doi.org/10.1016/j. envres.2019.108922.

ECJ European Court of Justice, 2008. Judgement of 1 April 2008on joined cases ECJ C14/06 and C-295/06. Orkesterjournalen C 116, 51.

Reporting, 2019. Reporting Eurostat [WWW Document], n.d, 12.23.19. https://ec.euro pa.eu/eurostat/web/waste/reporting/2019.

Fang, M., Choi, S.-D., Baek, S.-Y., Park, H., Chang, Y.-S., 2011. Atmospheric bulk deposition of polychlorinated dibenzo-p-dioxins and dibenzofurans (PCDD/Fs) in the vicinity of an iron and steel making plant. Chemosphere 84, 894-899. https://doi. org/10.1016/j.chemosphere.2011.06.016.

François, F., Blondeel, M., Bernaert, P., Baert, R., 2004. Diffuse emissions of PCDD/F and dioxin-like PCB from industrial sources in the Flemish region (Belgium). Organohalogen Compd. 66, 906-912.

Granier, L., Chevreuil, M., 1997. Behaviour and spatial and temporal variations of polychlorinated biphenyls and lindane in the urban atmosphere of the Paris area, France. Atmos. Environ. 31, 3787-3802. https://doi.org/10.1016/S1352-2310(97) 00210-0.

Grassi, P., Fattore, E., Generoso, C., Fanelli, R., Arvati, M., Zuccato, E., 2010. Polychlorobiphenyls (PCBs), polychlorinated dibenzo-p-dioxins (PCDDs) and dibenzofurans (PCDFs) in fruit and vegetables from an industrial area in northern Italy. Chemosphere 79, 292-298. https://doi.org/10.1016/j. chemosphere.2010.01.028.

Han, X., Meng, L., Li, Y., Turyk, M., Yang, R., Wang, P., Xiao, K., Zhao, J., Zhang, J., Zhang, Q., Jiang, G., 2020. Associations between the exposure to persistent organic pollutantsand type 2 diabetes in East China: A case-control study. Chemosphere 241, 125030. https://doi.org/10.1016/j.chemosphere.2019.125030. 
Harley, K.G., Marks, A.R., Chevrier, J., Bradman, A., Sjödin, A., Eskenazi, B., 2010. PBDE concentrations in women's serum and fecundability. Environ. Health Perspect. 118, 699-704. https://doi.org/10.1289/ehp.0901450.

Hearn, L.K., Hawker, D.W., Mueller, J.F., 2012. Dispersal patterns of polybrominated diphenyl ethers (PBDEs) in the vicinity of an automotive shredding and metal recycling facility. Atmospheric Pollution Research 3, 317-324. https://doi.org/ 10.5094/APR.2012.035.

Hovmand, M.F., Vikelsøe, J., Andersen, H.V., 2007. Atmospheric bulk deposition of dioxin and furans to Danish background areas. Atmos. Environ. 41, 2400-2411. https://doi.org/10.1016/j.atmosenv.2006.10.036.

Ji, H., Liang, H., Wang, Z., Miao, M., Wang, X., Zhang, X., Wen, S., Chen, A., Sun, X., Yuan, W., 2019. Associations of prenatal exposures to low levels of Polybrominated Diphenyl Ether (PBDE) with thyroid hormones in cord plasma and neurobehavioral development in children at 2 and 4 years. Environ. Int. 131, 105010. https://doi. org/10.1016/j.envint.2019.105010.

Langer, P., Kočan, A., Tajtáková, M., Rádiková, Ž., Petrík, J., Koška, J., Kšinantová, L., Imrich, R., Hučková, M., Chovancová, J., Drobná, B., Jursa, S., Bergman, A., Athanasiadou, M., Hovander, L., Gašperíková, D., Trnovec, T., Šeböková, E., Klimeš, I., 2007. Possible effects of persistent organochlorinated pollutants cocktail on thyroid hormone levels and pituitary-thyroid interrelations. Chemosphere 70, 110-118. https://doi.org/10.1016/j.chemosphere.2007.06.046.

Lauby-Secretan, B., Loomis, D., Grosse, Y., Ghissassi, F.E., Bouvard, V., BenbrahimTallaa, L., Guha, N., Baan, R., Mattock, H., Straif, K., 2013. Carcinogenicity of polychlorinated biphenyls and polybrominated biphenyls. Lancet Oncol. 14, 287-288. https://doi.org/10.1016/S1470-2045(13)70104-9.

Lee, W.-J., Su, C.-C., Sheu, H.-L., Fan, Y.-C., Chao, H.-R., Fang, G.-C., 1996. Monitoring and modeling of PCB dry deposition in urban area. J. Hazard Mater. 49, 57-88. https://doi.org/10.1016/0304-3894(95)00159-X.

Leijs, M.M., Koppe, J.G., Olie, K., van Aalderen, W.M.C., de Voogt, P., ten Tusscher, G. W., 2009. Effects of dioxins, PCBs, and PBDEs on immunology and hematology in adolescents. Environ. Sci. Technol. 43, 7946-7951. https://doi.org/10.1021/ es901480f.

Li, J., Zhang, G., Xu, Y., Liu, X., Li, X.-D., 2010. Dry and wet particle deposition of polybrominated diphenyl ethers (PBDEs) in Guangzhou and Hong Kong, South China. J. Environ. Monit. 12, 1730-1736. https://doi.org/10.1039/c001526a.

Liu, R., Ma, S., Li, G., Yu, Y., An, T., 2019. Comparing pollution patterns and human exposure to atmospheric PBDEs and PCBs emitted from different e-waste dismantling processes. J. Hazard Mater. 369, 142-149. https://doi.org/10.1016/j. jhazmat.2019.02.029.

Montalbano, A.M., Albano, G.D., Anzalone, G., Moscato, M., Gagliardo, R., Di Sano, C., Bonanno, A., Ruggieri, S., Cibella, F., Profita, M., 2020. Cytotoxic and genotoxic effects of the flame retardants (PBDE-47, PBDE-99 and PBDE-209) in human bronchial epithelial cells. Chemosphere 245, 125600. https://doi.org/10.1016/j. chemosphere.2019.125600.

Park, J.-S., Wade, T.L., Sweet, S.T., 2002. Atmospheric deposition of PAHs, PCBs, and organochlorine pesticides to Corpus Christi Bay, Texas. Atmospheric environment,
NADP 2000 - ten years after the clean air. Act Amendments 36, 1707-1720. https:// doi.org/10.1016/S1352-2310(01)00586-6.

Qu, C., Albanese, S., Lima, A., Hope, D., Pond, P., Fortelli, A., Romano, N., Cerino, P., Pizzolante, A., De Vivo, B., 2019. The occurrence of OCPs, PCBs, and PAHs in the soil, air, and bulk deposition of the Naples metropolitan area, southern Italy: implications for sources and environmental processes. Environ. Int. 124, 89-97. https://doi.org/10.1016/j.envint.2018.12.031.

Raffetti, E., Donato, F., Speziani, F., Scarcella, C., Gaia, A., Magoni, M., 2018. Polychlorinated biphenyls (PCBs) exposure and cardiovascular, endocrine and metabolic diseases: a population-based cohort study in a North Italian highly polluted area. Environ. Int. 120, 215-222. https://doi.org/10.1016/j. envint.2018.08.022.

Reddy, A.V.B., Moniruzzaman, M., Aminabhavi, T.M., 2019. Polychlorinated biphenyls (PCBs) in the environment: recent updates on sampling, pretreatment, cleanup technologies and their analysis. Chem. Eng. J. 358, 1186-1207. https://doi.org/ 10.1016/j.cej.2018.09.205.

Tasdemir, Y., Holsen, T.M., 2005. Measurement of particle phase dry deposition fluxes of polychlorinated biphenyls (PCBs) with a water surface sampler. Atmos. Environ. 39, 1845-1854. https://doi.org/10.1016/j.atmosenv.2004.11.041.

ter Schure, A.F.H., Agrell, C., Bokenstrand, A., Sveder, J., Larsson, P., Zegers, B.N., 2004. Polybrominated diphenyl ethers at a solid waste incineration plant II: atmospheric deposition. Atmos. Environ. 38, 5149-5155. https://doi.org/10.1016/j. atmosenv.2004.05.025.

Tian, M., Chen, S.-J., Wang, J., Shi, T., Luo, X.-J., Mai, B.-X., 2011. Atmospheric deposition of halogenated flame retardants at urban, E-waste, and rural locations in southern China. Environ. Sci. Technol. 45, 4696-4701. https://doi.org/10.1021/ es $200112 \mathrm{~m}$.

Turyk, M.E., Persky, V.W., Imm, P., Knobeloch, L., Chatterton, R., Anderson, H.A., 2008. Hormone disruption by PBDEs in adult male sport fish consumers. Environ. Health Perspect. 116, 1635-1641. https://doi.org/10.1289/ehp.11707.

Van den Berg, M., Birnbaum, L.S., Denison, M., De Vito, M., Farland, W., Feeley, M., Fiedler, H., Hakansson, H., Hanberg, A., Haws, L., Rose, M., Safe, S., Schrenk, D., Tohyama, C., Tritscher, A., Tuomisto, J., Tysklind, M., Walker, N., Peterson, R.E., 2006. The 2005 World Health Organization reevaluation of human and Mammalian toxic equivalency factors for dioxins and dioxin-like compounds. Toxicol. Sci. 93, 223-241. https://doi.org/10.1093/toxsci/kfl055.

Zhan, L., Lin, T., Cheng, H., Wang, Z., Cheng, Z., Zhou, D., Qin, Z., Zhang, G., 2019. Atmospheric deposition and air-soil exchange of polybrominated diphenyl ethers (PBDEs) in a background site in Central China. Environ. Sci. Pollut. Res. 26, 31934-31944. https://doi.org/10.1007/s11356-019-06312-6.

Zhang, M., Shi, J., Meng, Y., Guo, W., Li, H., Liu, X., Zhang, Y., Ge, H., Yao, M., Hu, Q., 2019. Occupational exposure characteristics and health risk of PBDEs at different domestic e-waste recycling workshops in China. Ecotoxicol. Environ. Saf. 174, 532-539. https://doi.org/10.1016/j.ecoenv.2019.03.010. 